\title{
DESIGN OF WEBSITE-BASED INFORMATION SYSTEM FOR E- DOCUMENT ADMINISTRASI IN THE COMMUNITY SERVICE UNIT (A Case Study at Rajabasa District)
}

\author{
Ochi Marshella Febriani(1), Tri Wahyuni(2), Suhendro Yusuf(3) \\ $(1,2,3)$ Lecturer, Department of Computer Scince, IBI Darmajaya, Indonesia
}

\begin{abstract}
District office is one of the government agencies. This office certainly produces documents in every administrative process and policy. The document management provides a good solution for each document in order to be accessed and used by users. The improper document management causes difficulty to find the needed documents. Moreover, the document is very difficult to access because it is only kept by certain people for various reasons. Besides, the document is also public rights that should be accessed by many people. An Act number14 in 2008 on Public Information Disclosure indicates that the document is a certain entity to reduce a public dispute so that it is mandatory matter that must be done. Under this condition, it is expected that the document must be stored in the website-based application to allow all parties to easily access the document stored.
\end{abstract}

\section{Key word}

\section{E-Document, District, Web}

\section{INTRODUCTION}

Document is one of the reports produced in an organizational order. The organizational order is started from planning, execution, reporting, and evaluation. Moreover, the role of this document also causes the document management which holds a very important role. One of the local governmental agencies implementing the document management is a district office. The district office is obliged to produce documents for the administrative and policy process. Besides, the document management also provides a good solution for its document in order to be accessed and used by users. An Act number14 in 2008 on Public Information Disclosure indicates that the document is a certain entity to reduce a public dispute so that it is mandatory that must be done. To solve real life problems and meet the needs, E-document is the solution carried out by lecturer-researchers, student-researchers, and publics [1] [2] [3]. One of the E-document usages in line with this article is made by $\mathrm{M}$. Ainul Yaqin, Karbila Barakah $\mathrm{H}$ with title of $\mathrm{E}$-Document-based management application using waterfall method. In this research, E-document was processed through PHP (Hypertext Preprocessor) my admin and database used as system design tool. The E-document design was processed by using inter-table relationship, data dictionary, coding system, hierarchy program, and flowchart program. The E-document was created for the several reasons e.g., (1) the absence of the design of the E-documentbased information system for the community service unit administration, especially in Rajabasa District; (2) the embodiment of the web-based information system as a part of the technology development; and, (3) the excellent effort to help publics and to obtain information quickly and effectively without limits.

Sommerville's Waterfall Model (2007) has several phases as follows:

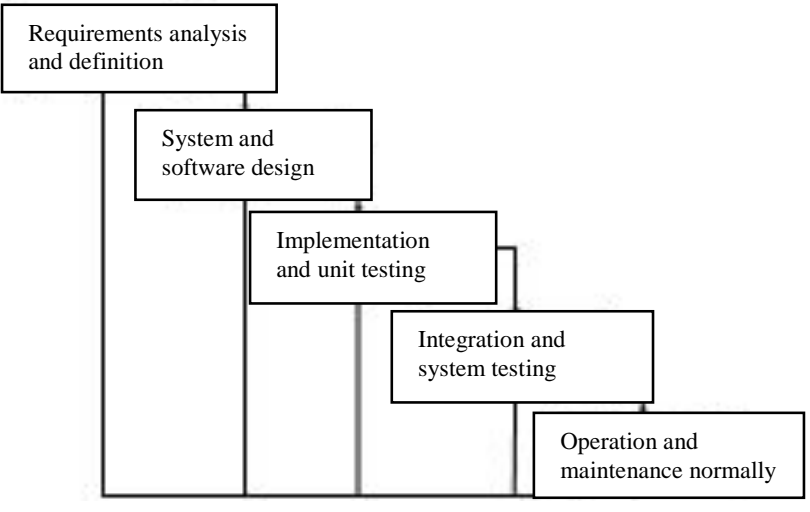

Figure 1. Waterfall Model

\section{a. Requirements analysis and definition}

Requirements analysis and definition were done on the provided data and used to collect the software requirements. This was the phase by which an initialization of the problem definition for the technical 
software development completion was begun. As the definition of the problem has been determined by the user and the developer, the termination analysis was conducted.

b. System and software design

It was necessary to convert the requirements into the characteristics which were understood by the software before writing the program. The processes which were carried out at this phase were:

$\checkmark$ To decompose the developed system module

$\checkmark$ To determine the required input and output design

$\checkmark$ To design the selected data structure

$\checkmark$ To determine the internal working procedures

$\checkmark \quad$ To determine the data processing formulas

c. Implementation and unit testing

The software design was conducted as a series of programs or program units in this phase. The unit testing involved a verification from which each unit met its specifications.

d. Integration and system testing

The program unit or the individual program in this phase was integrated and tested as a complete system to ensure that the system requirements were met.

e. Operation and maintenance normally

This phase caused the longest cycle. The maintenance encompassed a correction of the errors which were not found in the previous phase.

\section{Academic Discipline And Sub-Disciplines}

Web Programming, database

\section{Subject Classification}

Computer Science

\section{GENERAL DESCRIPTION OF THE SYSTEM}

This system was built through the data flow diagram, input/output design, inter-table relationship, data dictionary, coding system, hierarchy program, and flowchart program.

a. General description of the proposed system

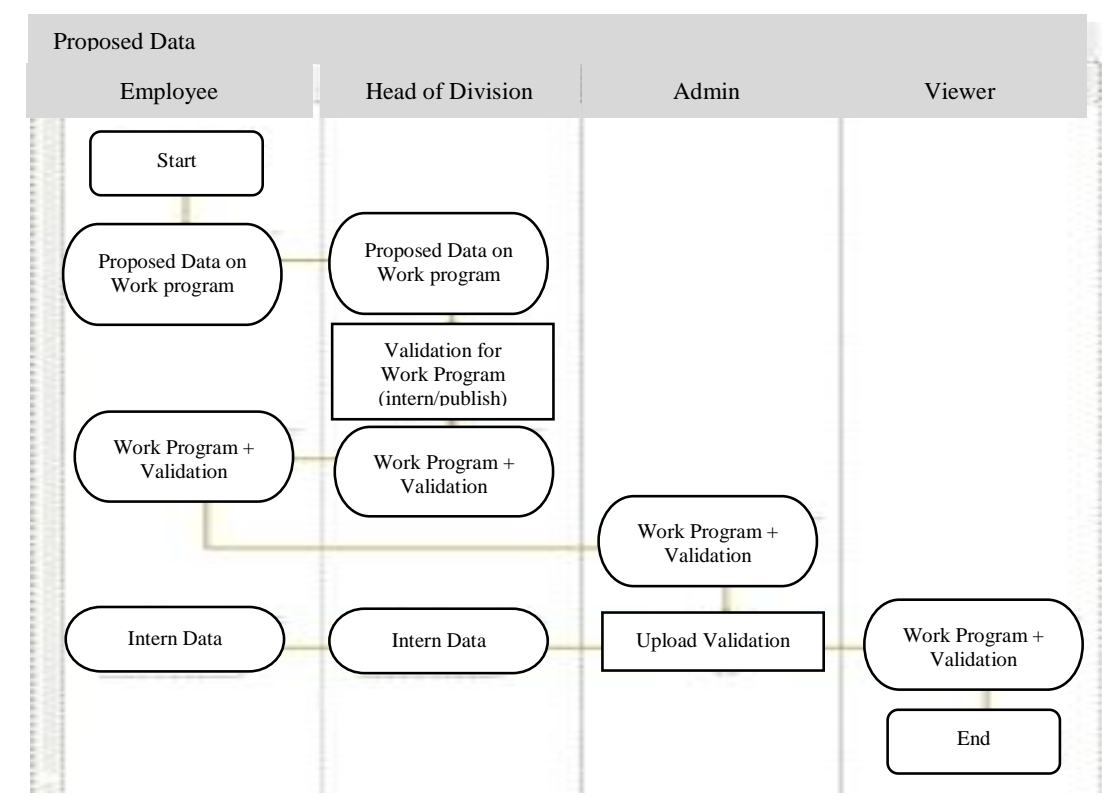

Figure 2. The Proposed System 
b. Database Design

Relational Database Model (RDBM) was often referred to the relational model or relational database. Relationship between 2 files or tables was categorized into 3 types.

1. One to one Relationship 2 file/ 1-to-1

2. One to Many Relationship 2 file/ 1-to-n

3. Many to Many Relationship 2 file/ $n$-to-n

To completely design the relationship description, there were 3 types of the relationship in one file (Suthanta, 2004). The 3 types of the relationships among tables as follows:

a. Relation among Tables

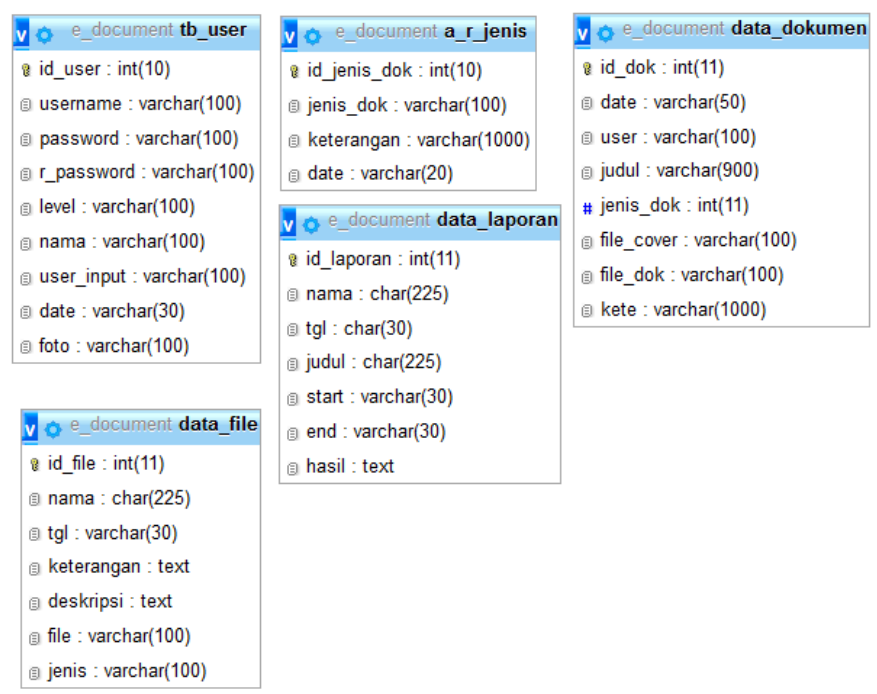

Figure 3. Relationships among tables

b. Data Dictionary

Some of the data dictionaries needed to support the proposed system were as follows:

1. Admin table

Database Name : e_document.sql

Table Name : tb_user

Primary Key : id_user

Foreign Key :-

\begin{tabular}{|l|l|l|}
\hline No & Name & Type \\
\hline 1 & Id_admin & Int (5) \\
\hline 2 & Uname & Varchar (20) \\
\hline 3 & Password & Varchar (20) \\
\hline 4 & Name & Varchar (20) \\
\hline
\end{tabular}

2. Table on Types of the Document

Database Name : e_document.sql

Table Name : a_rjenis

Primary Key : id_jenis_dok

Foreign Key 


\begin{tabular}{|l|l|l|}
\hline No & Name & Type \\
\hline 1 & Id_admin & Int (5) \\
\hline 2 & Uname & Varchar (10) \\
\hline 3 & Password & Varchar (10) \\
\hline 4 & Name & Varchar (20) \\
\hline 5 & Nip & Varchar (20) \\
\hline 6 & jk & Varchar (20) \\
\hline
\end{tabular}

c. Encoding System

Id consisted of 5 digits used to indicate the serial number installation.

Example : 001DC

001 : Queue of Id Number

DC : Document

d. Output Design

The E-document design was seen below.

Figure 4. Home Template

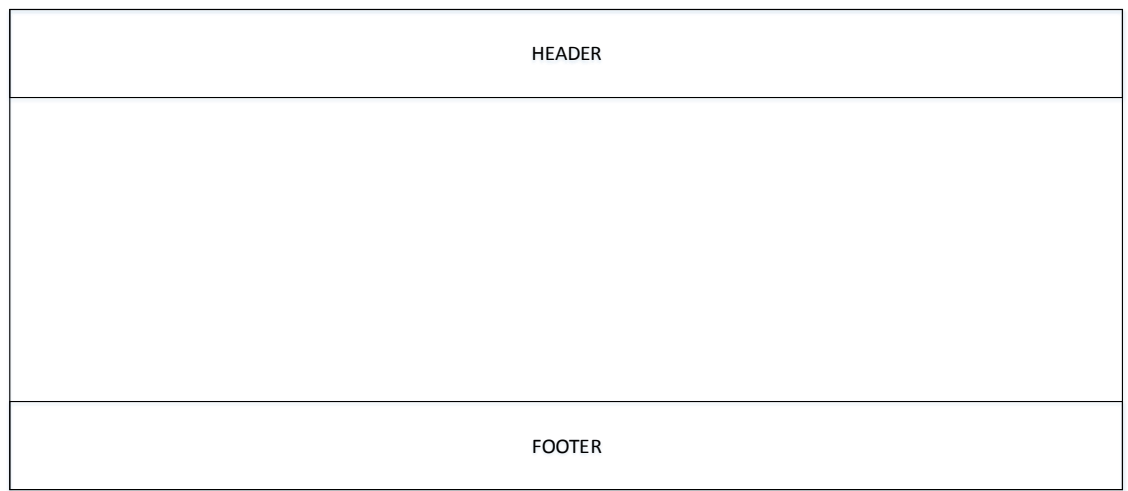

Figure 5 and 6. Design of Login for Admin

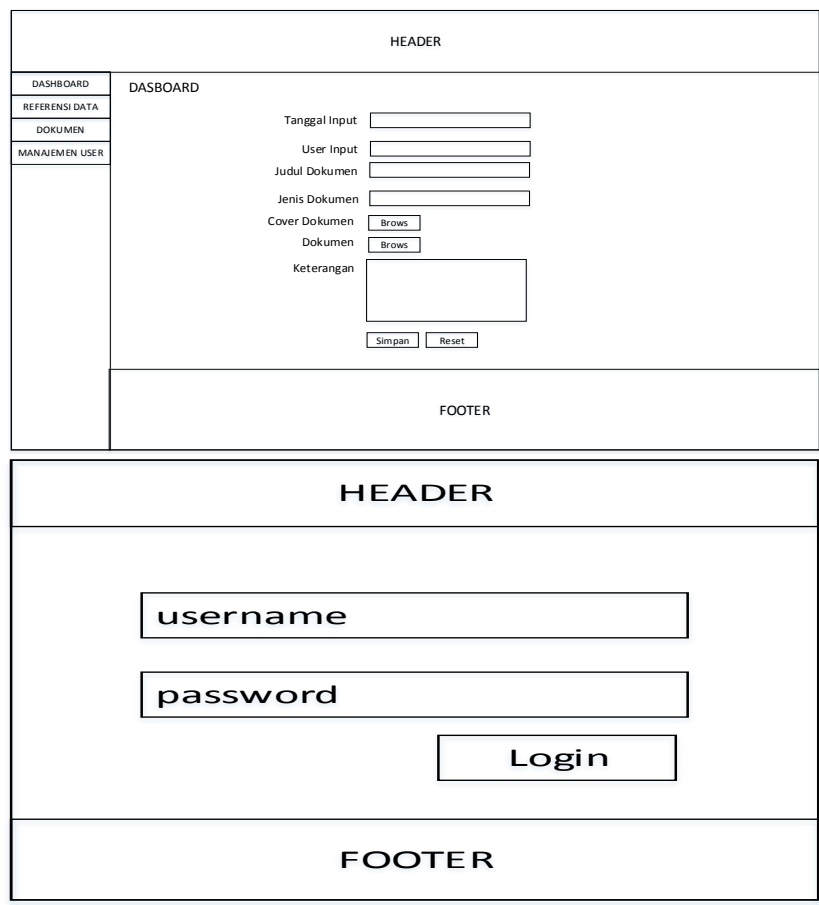

Figure 7. Design of Upload Document 


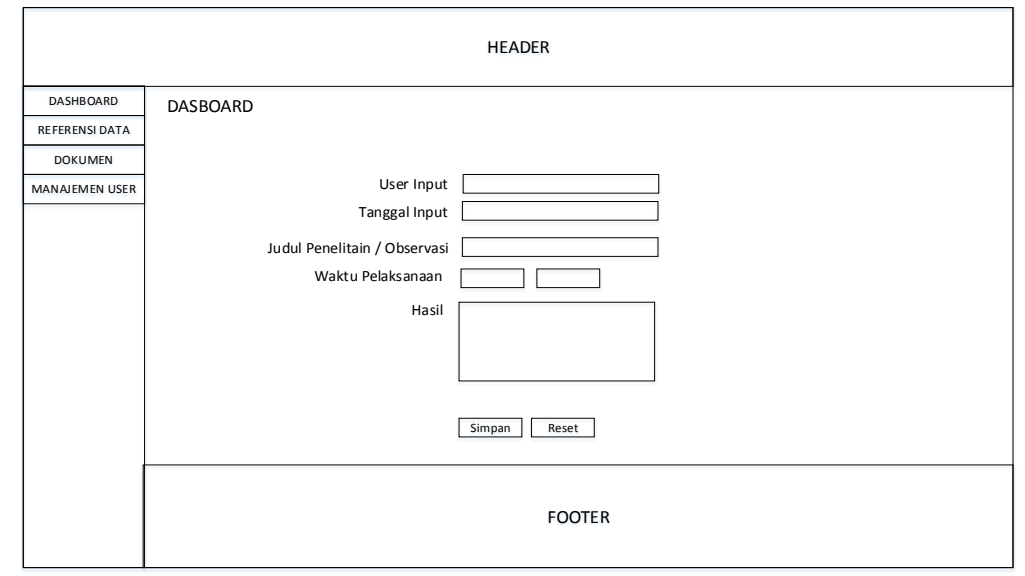

e. A Design of the proposed program logic (Figure 8 to 10) was as follows:

Figure 8. Flowchart of Login for Admin

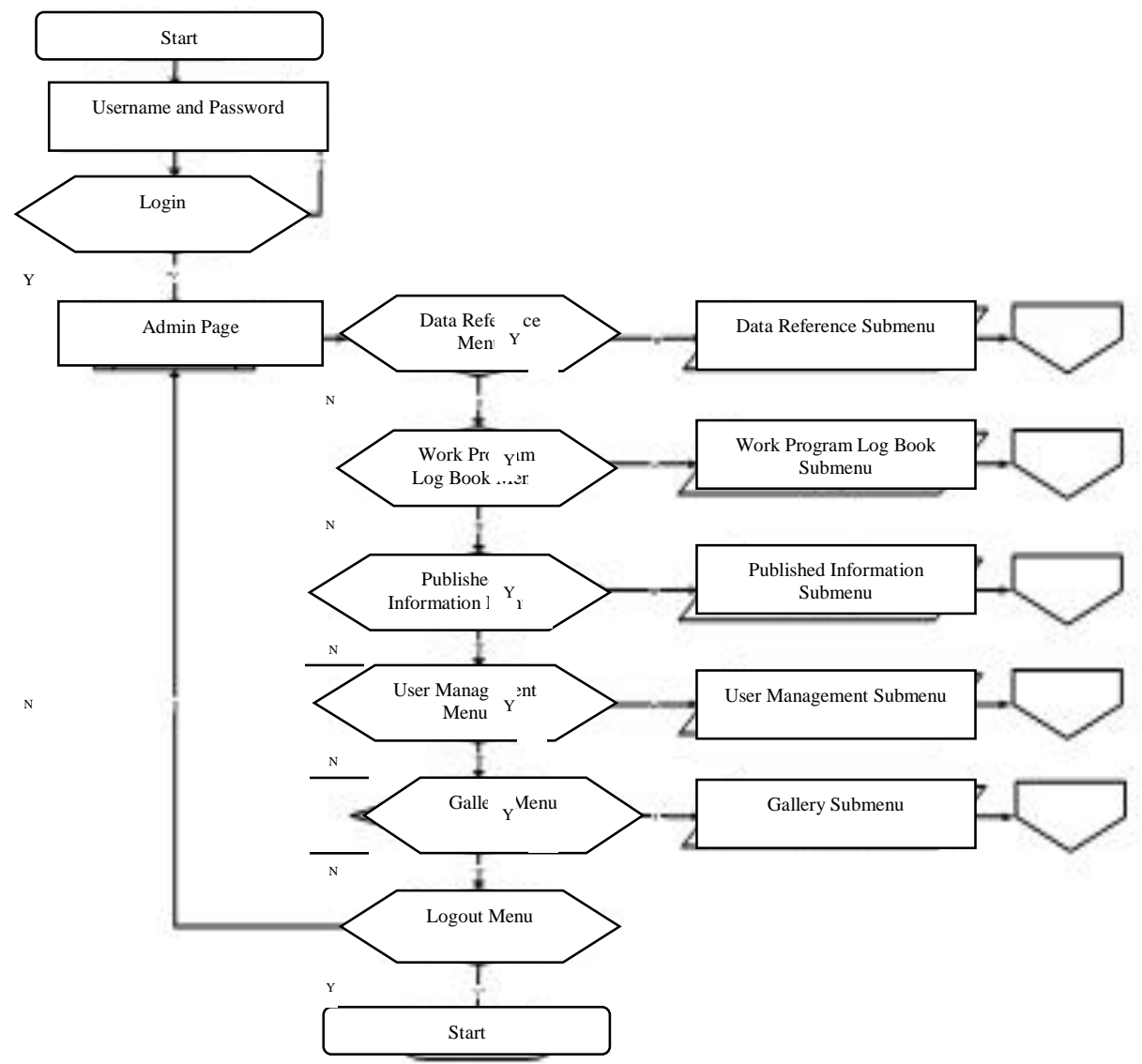

Figure 9. Flowchart of Submenu for Reference Data 


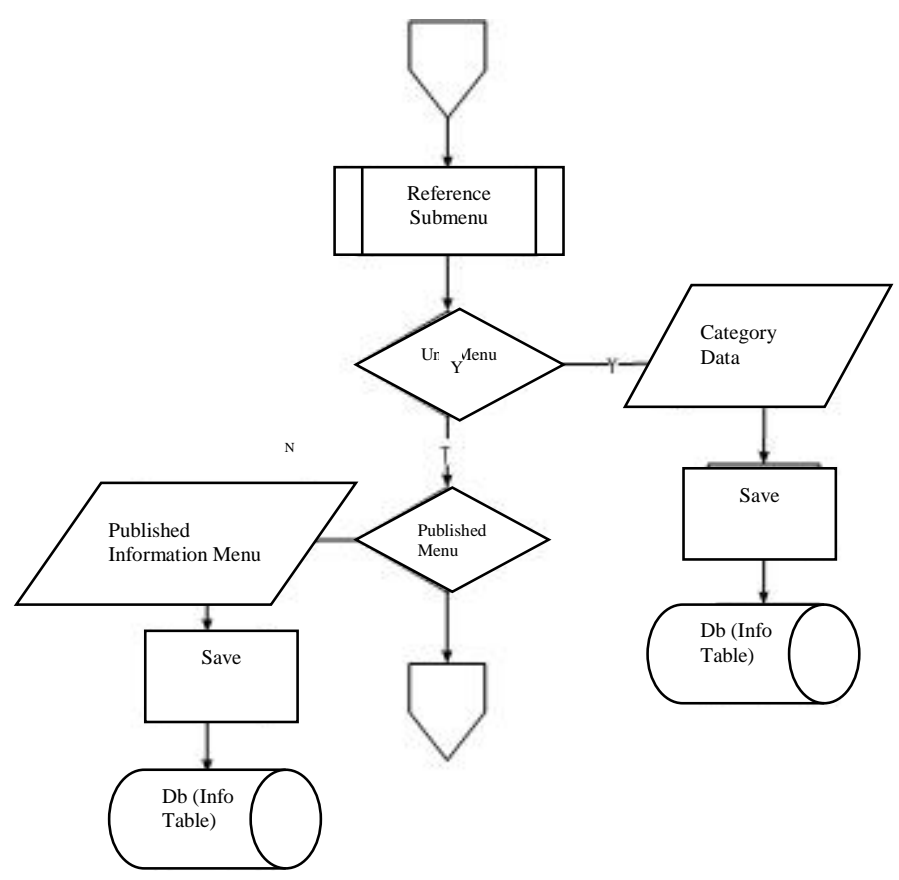

Figure 10. Flowchart of Submenu for Users
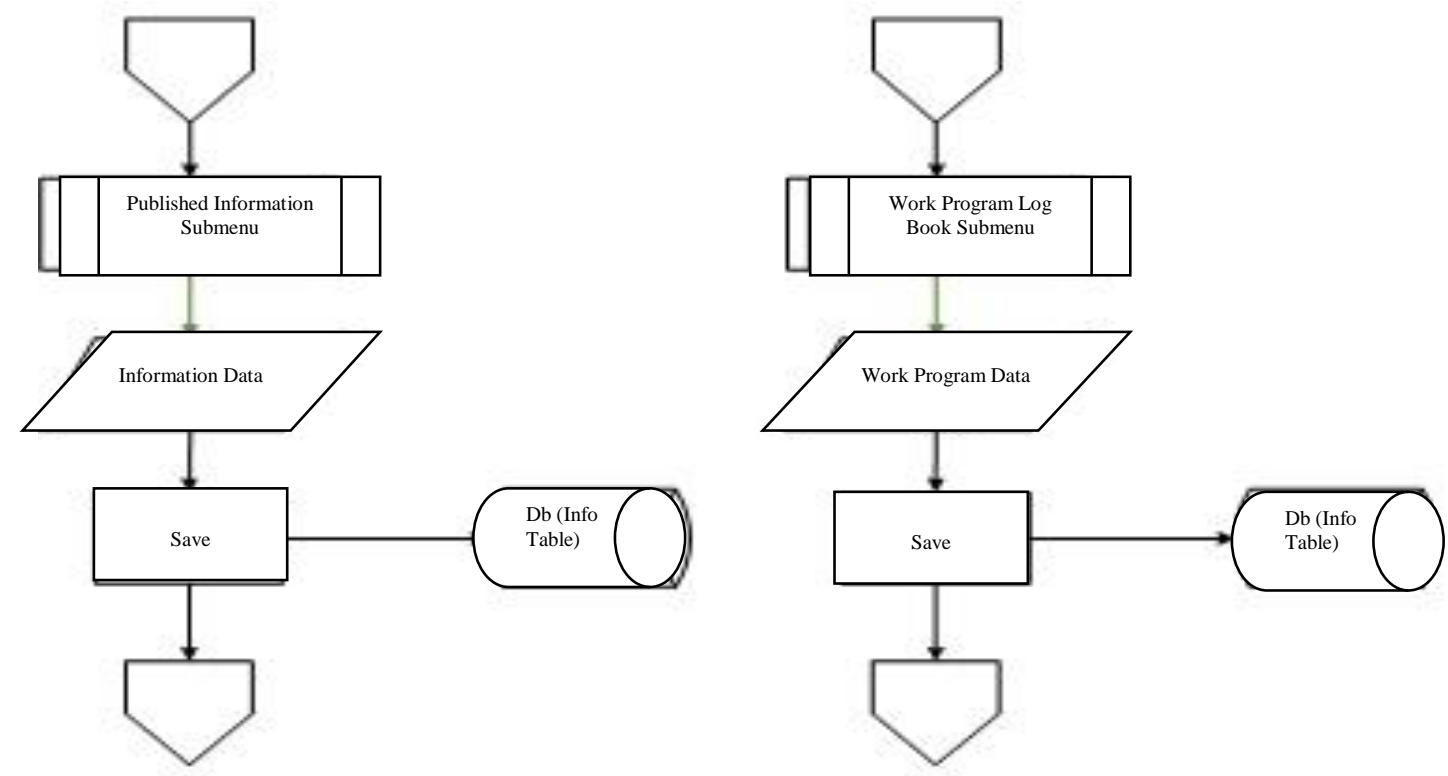

Figure 11 Flowchart of Submenu for Information Publish + Work Program Log Book 


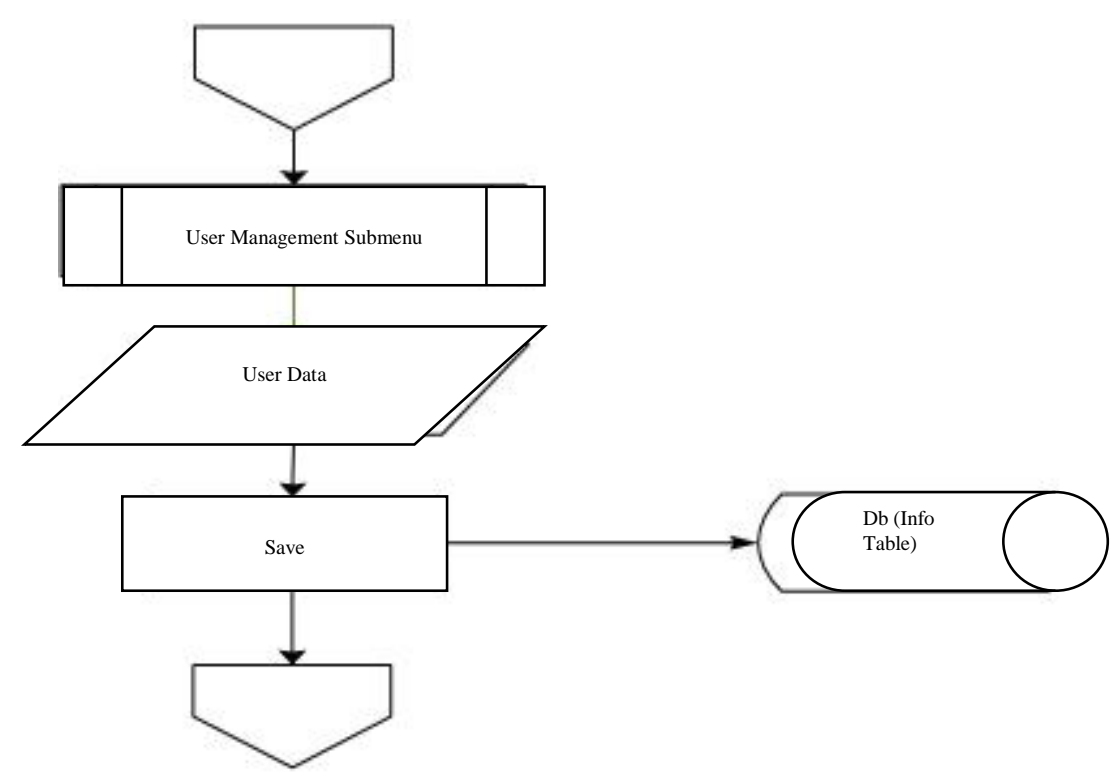

\section{HASIL PROSES}

a. The main page was the page that was firstly accessed by the user. There were several menus and galleries that was be accessed by publics. The following was attached to figure 12 :

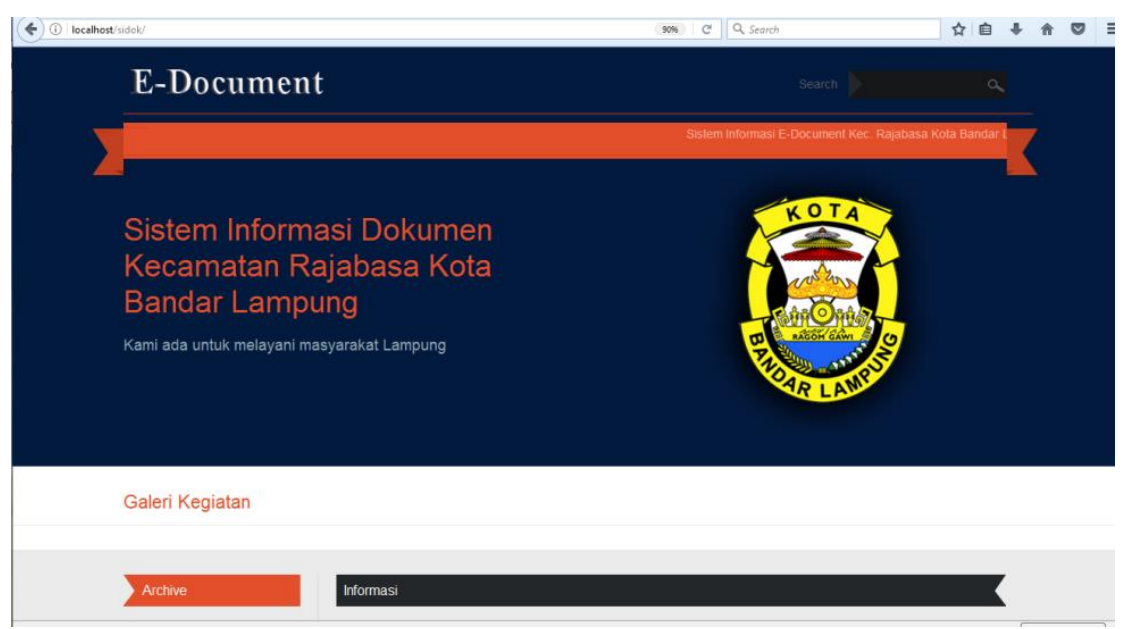

Figure 12. Main Page

b. Login page was a page accessed before entering the admin page. The picture 13 was as follows:

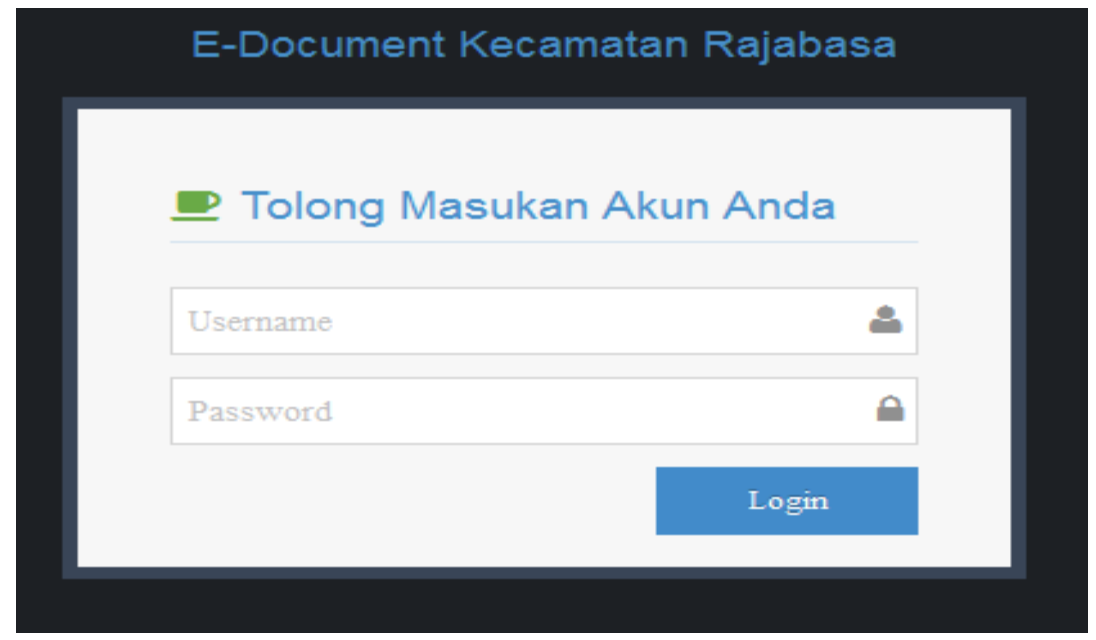

Figure 13. Login Page 
c. Information and share page was the page used to input information (activities/procedures/rules) for the community in Rajabasa District. The picture 14 was as follow:

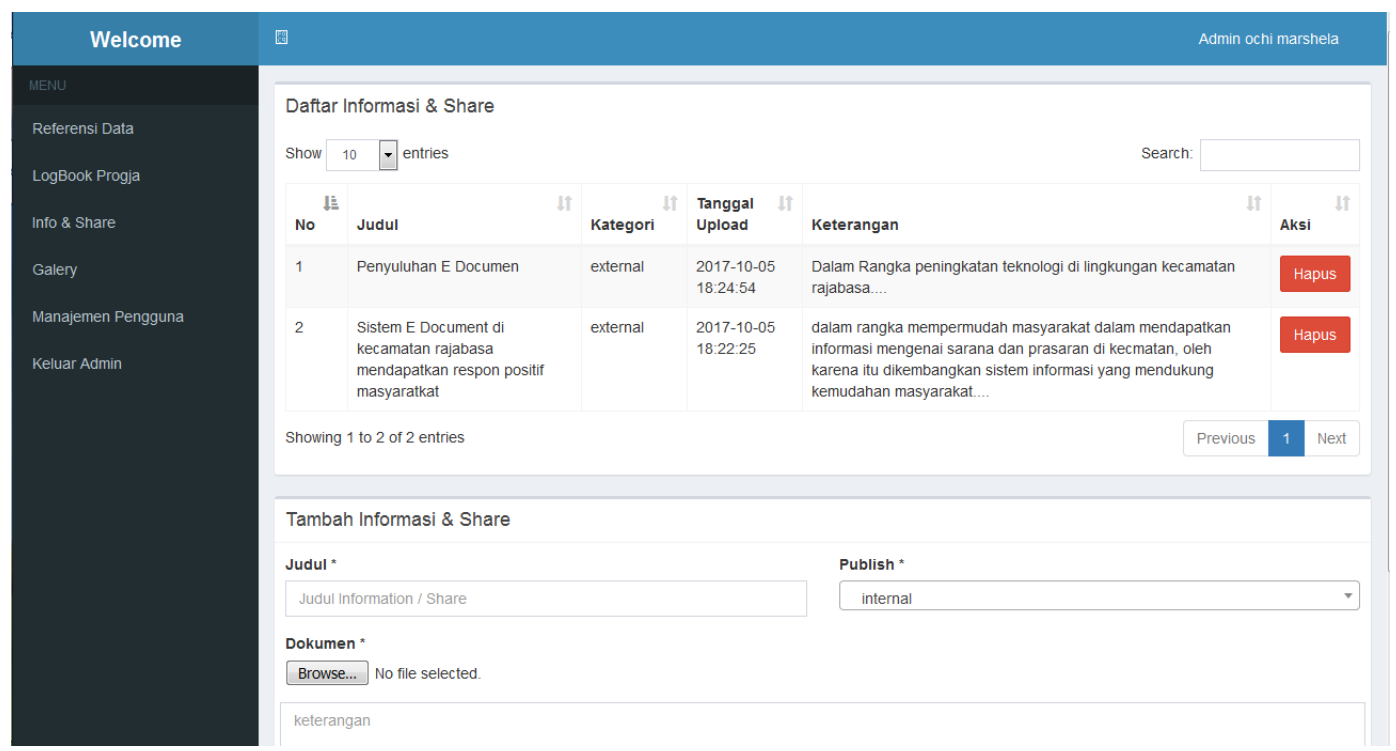

Figure 14. Information and Share Page

d. Work Program Log Book page was the page about work program activities conducted per division in Rajabasa District with planning report and work program implementation. Picture 15 was as follow:

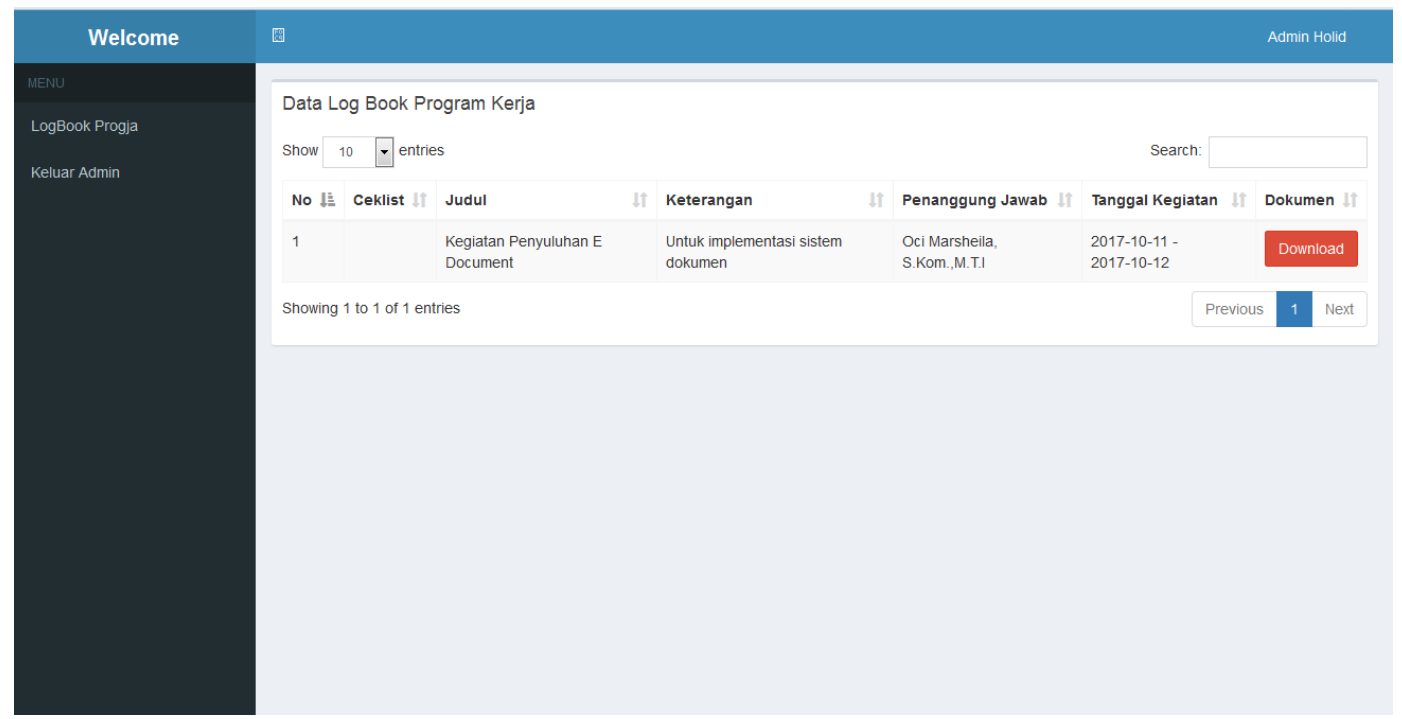

Figure 15. Work Program Log Book Page

e. The user management page was used to manage the user system e.g., new users, access rights, and deleted users. The picture 16 was as follow: 


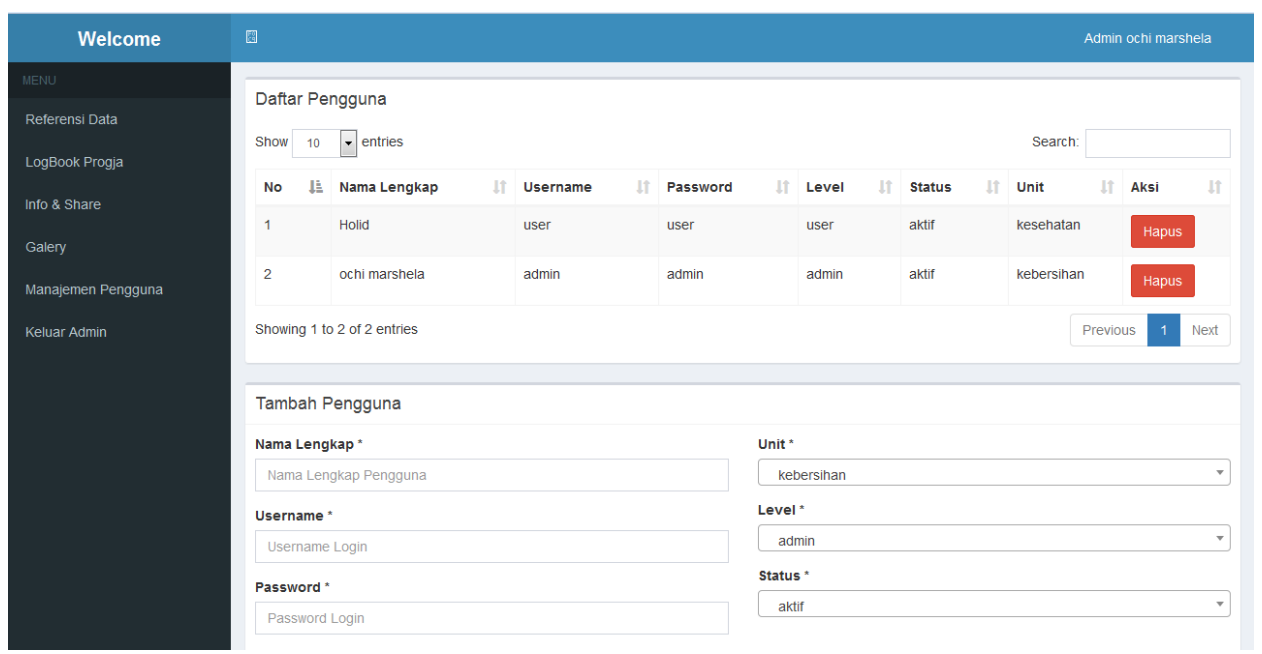

Figure 16. User Management Page

f. Reference unit page was the work unit page in Rajabasa District. This page was registered into the system. The picture 17 was as follow:

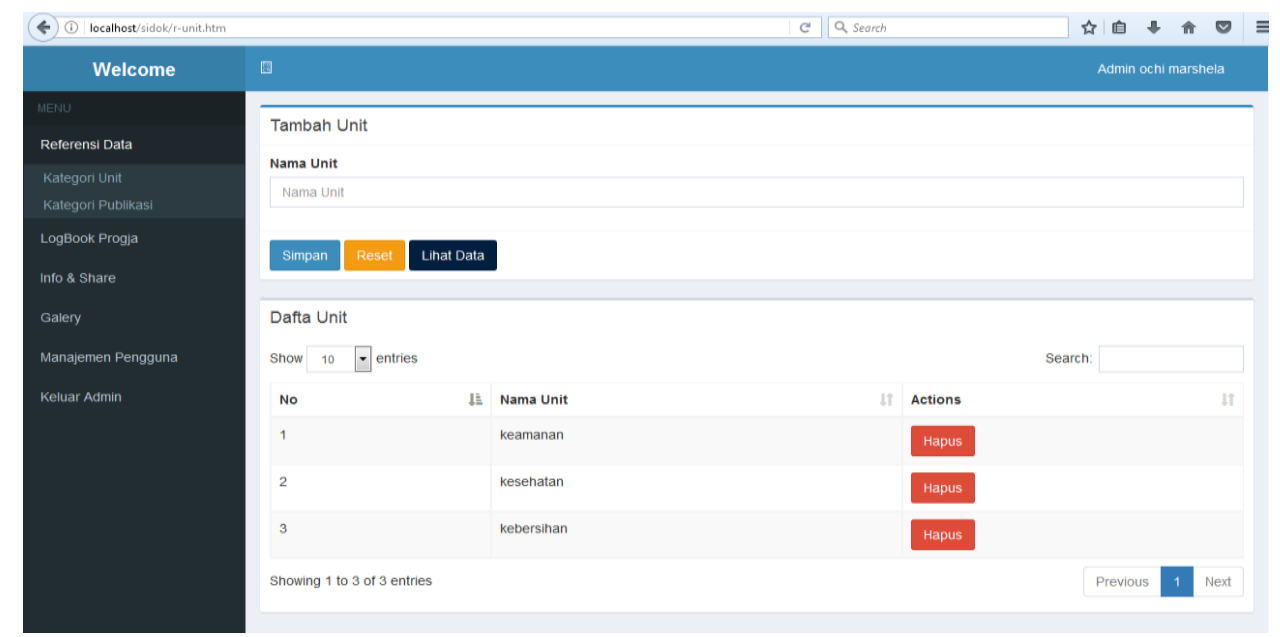

Figure 17. Reference Unit Page

g. Publish category page was the page to input the publication category in Rajabasa District (internal and external only). The picture 18 was as follow:

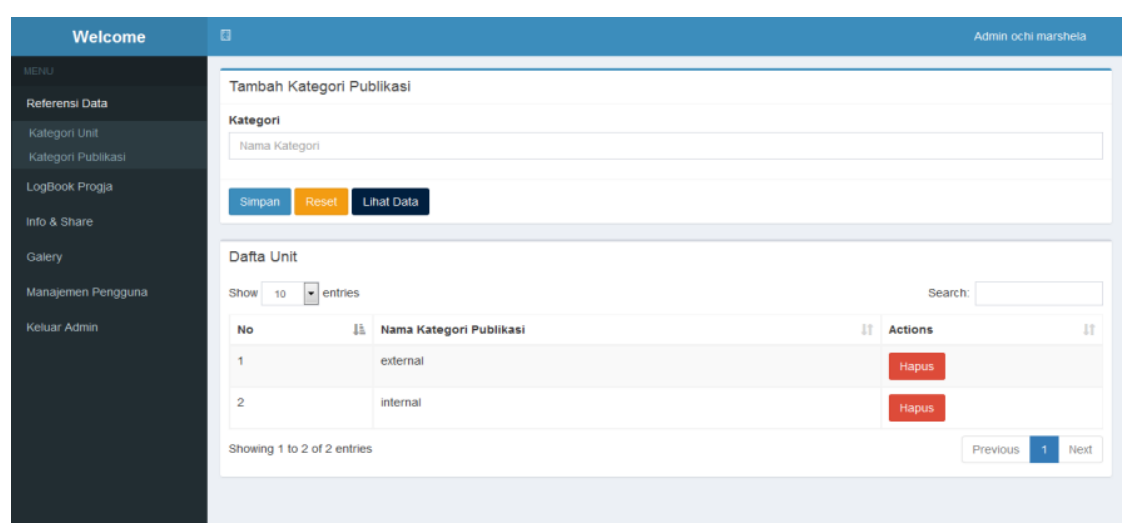




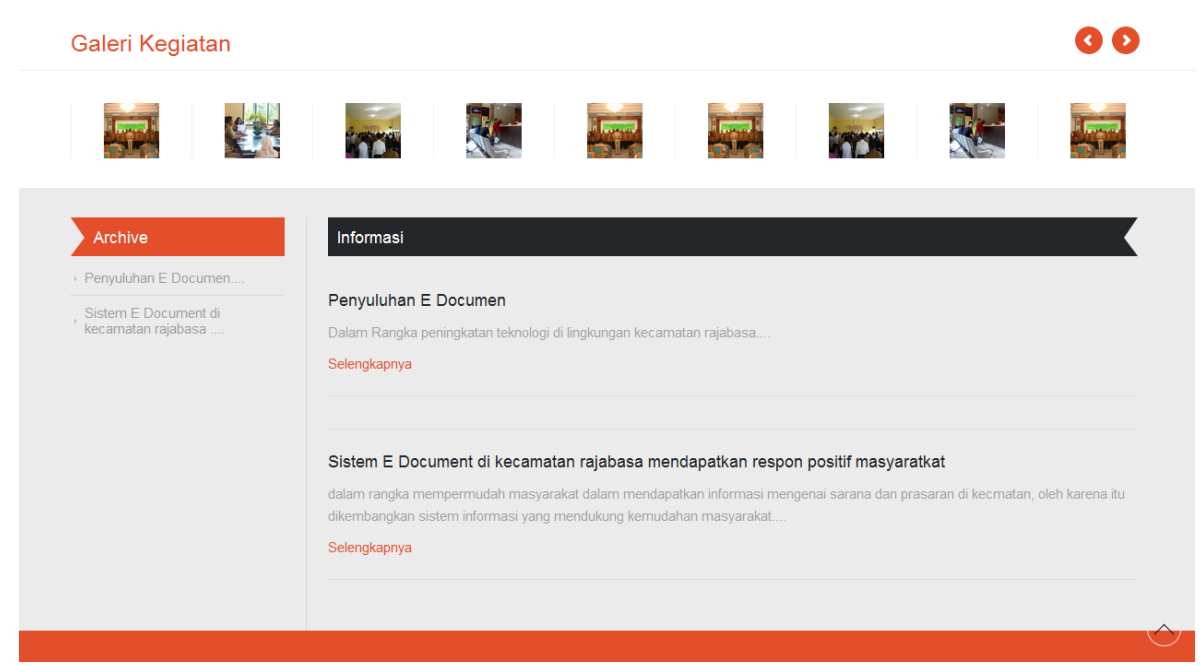

Figure 18. Publish Category Page

\section{CONCLUSION}

According to the data above, it can be concluded that:

1. The ongoing system has not used the supporting application and the database management used to increase activities and data archiving process on the relevant departments so that the performance was still not maximized. Thus, a system was needed to support administrative performance in the form of E-document.

2. The system made by the researchers facilitates the data search and storage so that the use of Internet media was maximally used as a mean of information.

\section{ACKNOWLEDMENT}

We would like to declare a inbounded gratitude to the Ministry of Research and Technology of Higher Education in Jakarta for financing this research. Furthermore, we also thank to the institution of the research and learning development and community service of Informatics and Business Darmajaya, Bandar Lampung. We also thank the colleagues who have supported us so that this scientific article can be completed.

\section{REFERENCES}

[1] Marissa alfia rahcmah, arief rahman "perancangan e-document system berbasis web sebagai upaya penerapan lean proses dalam administrasi dokumen ". URL : http://Digilib.its.ac.id > public>lTS-paper30086-2508100135-paper.pdf

[2] M. Ainul yaqin, karbila barakah "Aplikasi manajemen E-Document"

URL : https://yaqinov.wordpress.com/2013/11/23/aplikasi-manajemen-e-document

[3] URL: http://ejournal.uin-suska.ac.id/index.php/RMSI/article/view/1316/0

[4] Nugroho Bunafit . 2003. Aplikasi Web Database dengan Macromedia Dreamweaver. Yogyakarta: Andi

[5] Dennis, Alan., Wixom, Barbara Haley dan Roth, Roberta M. (2009), System Analysis and Design (Fourth Edition), John Wiley \& Sons, New Jersey

[6] Al-Bahra bin Ladjamudin. 2005. AnalisisdanDesainSistemInformasi. Yogyakarta :Grahallmu.

[7] Waterfall metode :(Sommerville:2007)

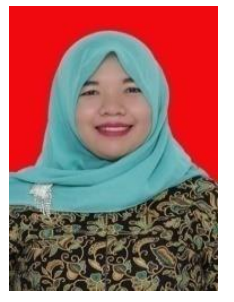

Ochi Marshella Febriani finished graduate degree in Informatics and Business Institute Darmajaya in 2012. He works as a researcher in Informatics and Business Institute Darmajaya. His interests are audit information system and database. 


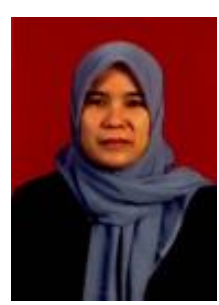

Tri Wahyuni finished graduate degree in Informatics and Business Institute Darmajaya in 2012. He works as a researcher in Informatics and Business Institute Darmajaya. His interests are informatics engineering and software engineering.

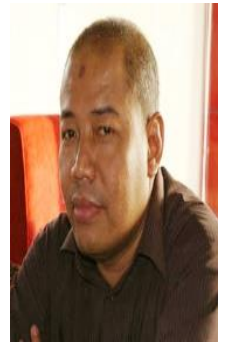

Suhendro Y. Irianto received his Master in Computers Science from The University of Indonesia, Jakarta Indonesia. He got Ph.D degree in Image Retrieval from the University of Bradford, United Kingdom in 2008. Currently, he works as the researcher in Informatics Engineering Department, Informatics and Business Institute Darmajaya, Indonesia. His interests are image retrieval, biometrics, pattern recognition, and multimedia database.

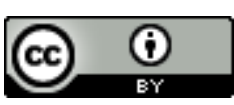

This work is licensed under a Creative Commons Attribution 4.0 International License.

DOI: $10.24297 /$ ijct.v16i7.6396 